\title{
Margaret Atwood, World-Famous but Yet to Be Discovered by Many Slovene Readers
}

\section{Tomaž Onič, Michelle Gadpaille, Jason Blake, Tjaša Mohar}

\begin{abstract}
Margaret Atwood is the only Canadian author whose $80^{\text {th }}$ birthday in 2019 was celebrated by the global academic community. This is not surprising, as she is the most famous Canadian writer, popular also outside literary circles. On this occasion, Slovene Canadianists organized a literary event at the Maribor University Library, which presented an outline of Atwood's oeuvre and a selection of translated poems and excerpts of prose texts; some of these were translated especially for the event. Of Atwood's rich and varied oeuvre, only eight novels, a few short fiction pieces and some thirty poems have been translated into Slovene. This article thus aims at presenting those aspects of Atwood's work which are less know to Slovene readers. It is no secret that Atwood is often labelled a feminist writer, mostly on account of The Handmaid's Tale and the TV series based on the novel. However, many Slovene readers may not know that she also writes poetry, short fiction, non-fiction and children's literature, that she is a committed environmentalist, and that she discussed the problem of "Debt and the Shadow Side of Wealth" in a prestigious lecture series. There are not many authors who master as many genres as Atwood and who are so well-received by readers and critics alike. The latter is true of Atwood also in Slovenia, and we can only hope that Slovene publishers will make more of Atwood's work available to Slovene readers. All the more so since Atwood has no plans to end her career: just before her $80^{\text {th }}$ birthday she was on a tour in Europe promoting her latest novel, The Testaments, and she would have continued touring in 2020 were it not for the COVID pandemic.
\end{abstract}

Keywords: Margaret Atwood, Canadian Literature, Literary Translation, Genres 


\section{INTRODUCTION}

Margaret Atwood's 80th birthday on November 18 in 2019 was celebrated globally. The academic community responded with a plethora of activities: from conferences and symposia, to thematic publications, as well as more-Atwood-thanusual in the lectures and seminars. Among the events taking place at the Maribor University Library was Fourscore and More: Margaret Atwood at Eighty, which presented a critical outline of Atwood's oeuvre, mediated by translations of excerpts from her work - not enough of which has been available to Slovene readers. The event was collaborative, operating as a dialogue between the organizing scholars and the student translators and readers, and reflecting the interaction between experts and beginners, between translators and literary scholars, between departments, and between Faculties.

Inspired by the Maribor Library event, this paper offers a selective overview of Atwood's writing, focusing on those works likely to be of most interest to readers and students in the Slovene cultural space. This contribution also addresses the question of how much - or how little - of her work is available in Slovene.

The Fourscore and More: Margaret Atwood at Eighty event opened on a personal note. Jason Blake, a Canadian transplanted to Slovenia and one of the authors of this article, shared with the audience several fragments that - directly or indirectly - relate his life to Atwood's life, colouring it little ways that also serve to connect the two countries. Since this account offers an engaging overview of Atwood's oeuvre from the Slovene perspective, we give here a selection of Blake's remarks:

In literary circles, Canada, until recently, was tiny indeed. All the authors knew each other, and even today it seems that every author has an anecdote about Captain Canada, Margaret Atwood - the woman who, it sometimes seems, single-handedly put Canadian literature on the world map.

I've never met Margaret Atwood, but she has affected my life in small ways. Years ago, we shared a moment. I was strolling down Admiral Road, a leafy, windy, fancy street in the middle of Toronto, and I saw someone struggling in the small garden in front of her house - spoiler alert: it was Margaret Atwood. She yanked, grunted, yanked some more, and turned around to see me seeing her having won against a bit of quackgrass, or chickweed, or perhaps knotweed. She looked proud of herself. She had defeated and uprooted that weed. So, Margaret and I shared a weed moment.

A few years later, I was working as a teaching assistant at the University of Toronto. We were on strike and the Margaret Atwood wrote an open letter in support of us. I found that classy because there was nothing in it for her yet she wrote bluntly and clearly about supporting future academics from the alma mater that gave her a "dandy education," about preferring to see alumni 
"contributions going towards quality education" rather "than towards some chunk of rock with our name on it."1

Atwood was once a guest on the BBC's weekly interview show Desert Island Discs and the conversation started with her years at Leaside High School, which I also attended, and which my two nieces now attend. She describes the school more fully in her novel Cat's Eye, but it also features in various ways in some of Atwood's books, so I get a touch of nostalgia when I read her. In a story called the "Age of Lead," Vincent takes Jane to "the graduation formal" (Wilderness Tips, 126), where high school kids would dress up in finery, give each other boutonnieres and corsages, and act silly. But, most famously, Atwood turned Leaside High into the prison for the dystopian The Handmaid's Tale, including the space described in the opening scene - with that "balcony [that] ran around the room, for the spectators..." (3).

Obviously, I no longer live in Canada, but sometimes I forget where I am and am whisked back to the Toronto in which Atwood and I grew up, not least when I read Atwood's work and try to spot the veiled and overt (and non-existent) references to streets and environs I know.

\section{ATWOOD'S FICTION, SHORT FICTION AND MINI FICTION}

\section{Novels}

Atwood's early novels The Edible Woman (1969), Surfacing (1972), Lady Oracle (1976), Life Before Man (1979) and Bodily Harm (1981) all ground themselves in Canadian themes and locations, although each was adopted by the international literary community, especially by feminist critics. After The Handmaid's Tale (1985), Atwood's fiction began to darken and move towards complex narrative and historical modes, with The Robber Bride (1993), Alias Grace (1996) and The Blind Assassin (2000). Cat's Eye (1988) turned to the Ontario of the author's childhood, and The Handmaid's Tale was a projection into the future of North America. To describe her fiction in one thematic or formal arc is impossible, but some unifying generalizations can be made. First, Atwood's own critical paradigm set out in Survival: A Thematic Guide to Canadian Literature (1972), her major work of criticism, has some utility in interpreting her fiction. Victim positions and their resolution recur in early works such as Surfacing and The Edible Woman, where female protagonists explore their own complicity in accepting social

1 Canadian Union of Public Employees Local 3902 deserves thanks for tracking down this 2000 letter for us. 
and personal subordination. More recently, The Testaments (2019), a sequel to The Handmaid's Tale, extends the dystopian exploration of gendered political victimhood to show female protagonists of varied ages rejecting victimhood to triumph over patriarchal power. The sisterhood of The Testaments proves more powerful than the oppressive system in the end. Simultaneously, The Testaments embodies two further trends in Atwood's fiction: first, towards narratives of older women, and second, towards increasing engagement with audience feedback and new media. For The Testaments is partly a response to the success of The Handmaid's Tale as a TV series and the public demand for information about Offred and her sisters in the reproductive slavery of Gilead. The narrative of aging has featured in Atwood's shorter fiction, as well, where Atwood experiments with a long view of women's lives, staging a life as an autobiographical memory constructed and de-constructed, before being offered as a testament to future readers (e.g., in the miniature tale "Life Stories"). Another unifying feature of this major oeuvre is its increasing engagement with the Internet and the new genres it has spawned, as Atwood embraces collaborative fiction, digital platforms and even post-human publication. This accompanies another trend in Atwood's fiction over fifty years: the flexible use of popular and high genres, a distinction that began to erode with Lady Oracle and continued with her playful use of comics, musicals (The Penelopiad, 2005) and B-movie scripts. With her trademark deadpan irony, Atwood ensures that the reader almost never knows when the joke is on them and on their petty amusements. Nevertheless, this fiction commands attention from any reader interested in the controllable outcome for our planet, since the later Atwood seems to be looking back at Earth from a privileged, infinitely distanced, but intimate position that combines age, experience and testimentary narration into a form of wisdom literature.

Various ranking lists place The Handmaid's Tale at the top of the Atwood popularity chart, as her finest novel (riding no doubt on the back of the successful television series). After that, it gets complicated. Indeed, if you were to ask ten Atwood fans which book should be translated next into Slovene, you would get ten different answers. This disagreement is a sign of Atwood's literary greatness and versatility. The COBISS library search system gives us a more quantifiable example of Atwood's versatility. Type Atwood's name into the search bar and you will be reminded that she dabbles in "social" novels, science fiction, crime, adventure, historical, and the somewhat opaque "other" novels.

Cat's Eye, her 1988 Künstlerroman or “artist's novel” about a successful painter returning to the Toronto where she grew up, would be our candidate for a work that deserves to be made available in Slovene. For Elaine Risley, the protagonist, returning from Vancouver on Canada's west coast to Toronto means remembrances of childhood friendships, growing pains, and bullying. "Little girls are cute and 
small only to adults," the artist narrator reminds us. "To one another they are not cute. They are life-sized" (CE 124).

\section{Speculative Fiction}

The turn towards speculative fiction first appeared in Atwood's short stories, before exploding in a futurist trilogy that began spectacularly with Oryx and Crake in 2003 and continuing with The Year of the Flood (2009). In Maddaddam (2013), the surviving, post-apocalyptic community lives with humanoids genetically engineered by the scientist Crake, who is a Dr. Frankenstein-like character. These Crakers are gentle vegetarians, who mate enthusiastically when pheromones are emitted and their backsides turn blue. However, they have no cultural heritage no stories of their own. So, Toby, one of the survivors of the man-made epidemic, begins to create this heritage for the Children of Crake by storytelling. Painstakingly, she gives them their Genesis, their Exodus and their fables, enduring many interruptions for their innocent questions. Here Atwood engages in a world-making exercise, akin to Tolkien's, and transforming her trilogy into the unusual genre of metafictional post-human speculative fiction.

Margaret Atwood denies that she writes science fiction despite her futurist trilogy. She does admit to speculative fiction, a genre to which many of her short prose pieces belong, for example "Three Novels I Won't Write Soon" (The Tent, 2006), in which various B-movie scenarios are proposed and discarded. Her speculation often concerns the corporatization of western culture, the devaluation of human capital when monetary capital takes precedence over both the natural environment and the human animals who inhabit it.

Atwood has no fear of technology, nor of the online world. Her futuristic novel The Heart Goes Last (2015) originated as a serial e-book and enjoyed an online comic spin-off. Its protagonist, Charmaine has bought the sales pitch of the great corporation, Consilience, and has entered their compound, where residents spend half their time in prison and half their time "free." The sales pitch sells this option as providing safety and predictability, where people down on their luck can escape poverty, precarity and the streets. It is, however, a concentration camp in all but name - and even its name provides a strong anagrammatic link: Positron = to prison.

\section{Short Stories}

Canadian novelist Hugh MacLennan once titled an article "Boy Meets Girl in Winnipeg, and Who Cares?" The point is (or was): a boy-meets-girl love story 
may be universal, but if you want Americans to read and buy your novel - that is, if you want to actually make a living as a writer - set your tale in New York, not Winnipeg. Atwood never took the road to New York. Her work almost always remains rooted in Canadian settings - and in The Handmaid's Tale, Canada is a sort of Shangri la, a place to escape to. When asked to deliver a series of lectures at Oxford University back in 1991, she opted for "terra incognita," that is, Canadian literature (ST 2). The lectures became the 1995 book Strange Things: The Malevolent North in Canadian Literature, which explored the concept of wilderness Gothic.

What makes Atwood tolerable as a voice of Canada is her ability to serve up quips, her outright humour, and her genius at interweaving the past and the present, even as she explores modern Canadian myths. "The Age of Lead" is a short story that delves into the mystery of the Franklin Expedition - a search for the Northwest Passage from West to East that left many robust men dead, including one John Torrington. "They took the lid off the coffin," writes Atwood, "and it was like those maraschino cherries you used to freeze in ice-cube trays for fancy tropical drinks: a vague shape, looming through a solid cloud" (Wilderness Tips, 120). It also prompted this Atwoodesque line from a Ljubljana student: "Well, you lick a cherry, but you should never lick a dead man."

Atwood begins her gem of short story "Gertrude Talks Back" like this: "I always thought it was a mistake, calling you Hamlet. I mean, what kind of name is that for a young boy? [...] The other kids at school used to tease the life out of you. The nicknames! And those terrible jokes about pork" (Good Bones, 16). The story is witty and insightful, as Gertrude finally gets a chance to speak. At the same time, however, Atwood, a colonial author raised on English literature and British imperialism, is taking playful aim at the most canonical and important work in the English language. Gertrude and Canada are talking back to Shakespeare.

\section{Slipstream}

Not all of Atwood's prose fits happily within the boundaries of the essay, the short story or the novel. Many of her shorter pieces defy classification, refuse to be mainstream and could belong in the new category called "slipstream." Where on the bookstore shelf does one put writing that is measured in lines and paragraphs rather than in pages? The short works in collections such as Murder in the Dark (from 1983), Good Bones (from 1992), or The Tent (from 2006) are often over before the bottom of the page. Are these prose poems? Parables? Short, short stories? Updated fairy tales? Or just witty jottings that would not have found a publisher had they not been by Atwood? 
Among these, "Life Stories" (The Tent, 2006) "Horror Comics" and "Simmering" (Murder in the Dark, 1983) defy genre classification, retaining the density of poetry, the thoughtfulness of the essay and the readability of fiction. "Life Stories" evokes the human hunger for autobiography, photograph albums, all the verbiage of lives both lived and witnessed. Then the ending cannibalizes itself, trailing away in a whisper:

I was born.

I was.

$($ Tent, 14$)$

These miniature prose creations are experimental, revelatory and horrifying, each in its own way.

\section{CHILDREN'S LITERATURE AND COMIC BOOKS}

Margaret Atwood has dabbled in many genres, including those for children. A few years ago, it came out that she would be writing the words for a comic book series. It was assumed this would be serious literature, graphic novels perhaps in the style of Art Spiegelman's Maus. Nothing of the sort! In the introduction to Angel Catbird, first published in 2016, Atwood writes, "Some find it strange that a person known for her novels and poetry would take to writing comic books... Why is a nice literary old lady like me ... messing around with flying cat-owl superheroes and nightclubs for cat people?" (np). Well, because it is fun and because comics are what she grew up on. Some of them "had an educational bent." The second and more recent graphic novel by Atwood is War Bears, which is set in WW II Canada and features a comic book writer. J. Caleb Mozzocco nominated it as "the sort of comic book story that will at least be of interest to almost anyone interested in the medium" (2019).

Some of Atwood's early books for children are didactic. This is true of For the Birds, a 1990 children's story beautifully illustrated by John Bianchi, about a young girl who meets a strange old lady who cares greatly about birds, and about the specific environmental dangers that harm them: the tall buildings they fly into, the monoculture forests, the air pollution, and... cats and kids that are out to get individual cardinals and blue jays in backyard gardens. Atwood educates, entertains and teaches us how to make birdfeeders. Her more recent children's books, however, are playful and feature outstanding book-long alliterations that can already be seen in the titles: Princess Prunella and the Purple Peanut, Rude Ramsay and the Roaring Radishes, Bashful Bob and Doleful Dorinda and Wandering Wenda and Widow Wallop's Wunderground Washery. 


\section{POETRY}

Atwood began publishing poetry in the mid-1960s. Her early collections - The Circle Game 1964; The Animals in That Country (1969); The Journals of Susanna Moodie and Procedures for Underground (1970) - gave Canadians elliptical, riddling short poems, with dream-like imagery, but a secure link to the founding writers of the past. The Journals of Susanna Moodie thus constructed a literary heritage for a country short on literary ancestors - particularly foremothers.

Atwood's main concern in her poetry is "to enter the wilderness of the self," as critic Rosemary Sullivan says in The Concise Oxford Companion to Canadian Literature (22). Across 17 volumes of poetry, including collected works, Atwood has kept her poems often deceptively simple, a clear voice leading the reader through imagery to a place of discovery, and then, just as calmly, snatching the discovery away.

Marriage is not

a house or even a tent

it is before that, and colder [...]. ("Habitation," Procedures for Underground, 60)

As a poet, she is often sly and tricky, shifting semantic ground between one line and the next: "I need wolf's eyes to see / the truth. ("Further Arrivals," The Journals of Susanna Moodie, 13).

These poems begin in the orderly world we take for granted, but the words soon lead us to a quicksand of language: we find ourselves facing the chaos and barbarism that lies beneath the surface of human culture, with "apocalypse coiled in [our] tongue" ("Spring Poem," You Are Happy, 22).

Her poetic journeys are sometimes topographical (into the northern wilderness), sometimes historical or psychological, and often mythological. In the 1990s, her poetry collections Morning in the Burned House (1995) and Eating Fire (1998) retreated from overt mythologizing to deceptively domestic scenes, as in the burned house of the collection's title: "In the burned house I am eating breakfast, / You understand: there is no house, there is no breakfast, / yet here I am" "Morning in the Burned House," Morning in the Burned House, 126). Her analogies still surprise, as in her Helen of Troy, the countertop dancer who is "naked as a meat sandwich" ("Helen of Troy," Morning in the Burned House, 33).

The house imagery recurs in the collection The Door (2007), where one poem "Resurrecting the dolls' house," opens with the safe, nostalgic image of an abandoned toy, but progressively erodes the protected home space of the western family. Atwood's gothic imagery can also be found in other poems: "Heart" begins from everyday linguistic idioms like "to lose one's heart" but takes idiom literally 
and ends in a scenario of bodily horror. Metaphorical literalization often underpins Atwood's poetic effects, as in "Your Children Cut Their Hands," which uses the metaphor of the mirror to express parental anguish at the life ordeals of the next generation.

From the same volume, "War Photo" and "War Photo 2" show Atwood's continuing engagement with victims of organized violence - those who come from places far removed from the relatively safe cocoon of Canada. Finally, the closing poem of the book, "The Door," calls on everything we know about rituals of passage to another world, to give us a new mythology of passing from old age to whatever lies beyond. Above all, Atwood's poetry treats language as a particularly subtle conspiracy theory; her readers should approach with due suspicion.

\section{ATWOOD'S ACTIVISM}

Atwood could afford to turn her back on the real world, but she does not. Every time the real world comes calling, this author opens the door. She opened it to care for fellow-writers in Canada and around the world, being a co-founder of both the Writer's Trust of Canada and of PEN Canada, the latter the organization that seeks justice for persecuted writers all around the world.

Atwood has long resided in Toronto and she keeps an eye on local affairs and concerns. She fought proposed cuts to Toronto's public library budget in 2011, and in 2013 she tweeted against the installation of artificial turf in the fields of the University of Toronto's back campus. Interventions such as these show that she tries to help keep the city green, literate and accessible for her fellow citizens.

To tackle the vital, real-world subject of money in 2008, Atwood published a collection of lectures called Payback: Debt and the Shadow Side of Wealth. ${ }^{2}$ It is about personal, national and cultural indebtedness. Atwood goes beyond mere numbers; she traces our notions of indebtedness back to ancient myth, and follows these concepts in our storytelling, through Dr. Faustus and his fatal bargain with the devil. Finally, Dickens's Scrooge becomes her template for exploring what people really owe, to whom and what it means to pay it truly back.

Atwood is a committed environmentalist. Her publishing house named O.W. Toad (an anagram of Atwood) was publishing on acid-free paper long before an environmental conscience became fashionable.

2 This prestigious Canadian Broadcasting Corporation series of lectures, named the Massey Lectures after Governor General of Canada Vincent Massey, started in 1961. Apart from Atwood in 2008, it has hosted such famous speakers as Martin Luther King, George Steiner, Claude Lévi-Strauss, Doris Lessing and Noam Chomsky. 
In her writing, Atwood's environmental awareness is reflected especially in the Maddaddam trilogy, which is sometimes categorized as an ecological apocalypse, or an environmental dystopia. However, Atwood's ecological concerns are already noticeable in her novel Surfacing (1972). The novel about a young woman investigating her father's disappearance is set in the bush of Northern Quebec, a place where Atwood herself spent part of her childhood. In the novel, the unnamed protagonist, accompanied by three friends, returns to the place where she spent her childhood. The four friends drive to Northern Quebec all the way from Toronto and stay at the cabin by the lake where the protagonist's father lived. It pains the protagonist to find the landscape changed where there used to be intact nature, and the signs of progress and tourism setting in. She is appalled by the sight of a dead heron, which was obviously slaughtered by tourists for mere pleasure. And when her friends ask her to take them fishing, she suddenly realizes that the killing of fish is an act of violation, for they do not need it for food. She is becoming increasingly aware that the tourists as well her own nation present a threat to nature and to the future of the humankind.

Atwood has often been labelled a feminist writer. The Handmaid's Tale and the TV series based on the novel have had a great influence on supporters of women's causes around the world; there have even been protests organized by women dressed like handmaid. Atwood, however, does not have a straight answer to the question whether she herself is a feminist: "I never say I'm an 'ist' of any kind unless I know how the other person is defining it" ("Do you consider...?"). And this is what she thinks about gender equality: "I believe women are full human beings (radical, I realize). And that laws should reflect this. However, men and women are not 'equal' if 'equal' means 'exactly the same.' Our many puzzlements and indeed unhappinesses come from trying to figure out what the differences really mean, or should mean, or should not mean. Last I looked, people were still trying. And yes, it has something to do with standard of living and available food supply. When times are better and women have jobs, their status goes up" ("Do you consider...?").

When Atwood's first novel The Edible Woman was published in 1969, it became a great success with the feminist movement that was on the rise at the time (Sullivan 1998, 247). Atwood, however, preferred it to be called "protofeminist" rather than feminist, for, as she explained in the 1980 preface, she was writing it in 1965, when there was no women's movement in sight (in Staines 2006, 17). She still believes that "the feminist label can only be given to writers who willfully and consciously work within the context of the movement" (qtd. in Oppenheim). The novel with this catchy and meaningful title features Marian, a young employee in a market research company, who develops an eating disorder after becoming engaged to a handsome and prosperous lawyer named Peter. Marian's body starts rejecting one kind of food after another, until she realizes that she herself has in 
a way become a consumable. She escapes Peter's party and the life that has been oppressing her. The day after the party, when Peter demands an explanation, she invites him to her place and offers him a cake in the form of a woman: "You've been trying to destroy me, haven't you,' she said. 'You've been trying to assimilate me. But I've made you a substitute, something you'll like much better. This is what you really wanted all along, isn't it? I'll get you a fork...' (EW 281). Peter flees.

\section{ATWOOD IN SLOVENE}

The body of Margaret Atwood's works accessible to Slovene reader cannot be claimed as minimal in absolute numbers - to date, the translations of eight longer texts, eight shorter pieces of fiction, as well as 30 individual poems have been published, which is more than for many writers from the English speaking world. Yet, considering Atwood's opus and influence, Blake's claim that "Slovenes have been cheated of many of Atwood's finest works" can be extended beyond the novel, to which it originally referred.

Atwood has published eighteen novels. ${ }^{3}$ Eight of these have found their way into Slovene, some with a considerable delay: Surfacing (1972), Lady Oracle (1976), The Handmaid's Tale (1985), The Blind Assassin (2000), Oryx and Crake (2003), The Penelopiad (2005), ${ }^{4}$ The Year of the Flood (2009), and The Testaments (2019). Soon after their publication in Slovene, Na površje (2004) and Leto potopa (2015) acquired braille versions. Some of the Slovene translations, particularly those published after 1990, including the critical response to them, were discussed by Onič, Mohar and Gadpaille (2019) in a paper within the Canada Consumed project that made an attempt to catalogue translations of Canadian literature into eight Central European languages, including Slovene.

None of Atwood's story or essay collections or poetry collections have been translated into Slovene, although individual shorter pieces and poems have appeared in various literary journals. The former include "Isis in Darkness," "Wilderness Tips," “The Sin Eater," "When It Happens," "Murder in the Dark," "Horror Comics," "The Page," and "The Eternal Triangle," while the 30 translated poems come from several collections.

3 Only seventeen, however, are accessible; Scribbler Moon, Atwood's 2014 contribution for the Future Library project by the artist Katie Patterson, remains sealed until 2114. See more at www.futurelibrary.no.

4 As a part of the international Canongate Myth Series, The Penelopiad was published in several countries simultaneously (including in Slovenia, by Mladinska knjiga). In this context, it is often considered a novella, while many scholars dealing with Atwood's opus count it among the novels.

5 Their Slovene titles are Na površje (2003), Preročišče (1987), Deklina zgodba (1990), Slepi morilec (2010), Zadnji človek (2004), Penelopina preja (2005), Leto potopa (2012), Testamenti (2019). 
Some of Atwood's poems and prose fragments were translated by the students of the Maribor Faculty of Arts translation program in preparation for the Fourscore and More event. Mentored by the literature and literary translation teachers, these were read at the University Library literary evening by the student translators themselves. The experience proved to be highly beneficial for all participants as the challenges, delights and depths of Atwood's writing came to the fore.

\section{CONCLUSION}

In her 1972 Survival overview of Canadian literature, Atwood made a case for why the Canadians should read Canadian literature: because it is "ours." Atwood does, however, remind readers of Survival not to "fall into the trap of praising something just because it's Canadian" (216) - she may be accused of nationalism, but not jingoism. Considering Atwood's global popularity, she undoubtedly takes the credit for putting Canadian literature on the map, while serving as a kind of ambassador of Canadian culture to many places, including Slovenia. She is also one of the few authors who are not only popular, but also well-received by highbrow critics. Although Atwood is certainly the most famous Canadian writer in Slovenia, ${ }^{6}$ much of her work remains to be discovered by Slovene readers, particularly her short fiction, non-fiction, poetry, and children's books. And she has no plans to end her career, for just before her 80th birthday, she was on a UK and Irish tour promoting her latest novel, The Testaments, and she would have continued touring in 2020 were it not for the unforeseen developments in these times of COVID.

\section{WORKS CITED}

\section{Primary Sources}

Atwood, Margaret. "Age of Lead.” In Wilderness Tips. McClelland \& Stewart, 1999 (1991), 120-133.

Atwood, Margaret. Cat's Eye. Doubleday, 1988.

Atwood, Margaret. The Edible Woman, EPUB. Emblem, 2010 (1969).

Atwood, Margaret. "Further Arrivals," In The Journals of Susanna Moodie. Oxford University Press, 1970, 12.

6 This despite the fact that her compatriot, the short story writer Alice Munro won the Nobel Prize in Literature in 2013. For more information on the popularity of the two authors in Slovenia, see the article "Alice Munro and Leonard Cohen: Ambassadors of Canadian Culture in Slovenia." 
Atwood, Margaret. "Gertrude Talks Back.” In Good Bones. Knopf Doubleday, 2011 (1992), 16-19.

Atwood, Margaret. "Habitation" In Procedures for Underground. Little, Brown \& Co, 1970, 50 .

Atwood, Margaret. The Handmaid's Tale. Random House, 2016 (1985).

Atwood, Margaret. Morning in the Burned House. Houghton Mifflin Harcourt, 1995. Atwood, Margaret. Strange Things: The Malevolent North in Canadian literature. Clarendon Press, 1995.

Atwood, Margaret. "Spring Poem," In You Are Happy. Oxford University Press, 1974, 22.

\section{Secondary Sources}

@MargaretAtwood.com. “So, @UofTNews: as a soon-to-be dead alum w. \$ to leave, am I annoyed by the anti-green plan? Y!" Twitter, March 12 2013. 7:06 p.m., https://twitter.com/margaretatwood/status/311553746582765569.

Atwood, Margaret. "Barbed Riposte from Margaret Atwood to Prichard." Received by the authors, 18 November 2019 .

Atwood,Margaret."Doyou consider yourself a feminist?"Web blog post. Goodreads. 2014, https://www.goodreads.com/questions/816-do-you-consider-yourself -a-feminist-how.

Desert Island Discs. "Margaret Atwood." Aired 13 April 2003 on BBC 4, https:// www.bbc.co.uk/programmes/p0093713.

MacLennan, Hugh. "Boy Meets Girl in Winnipeg and Who Cares?" In Scotchman's Return and Other Essays. Macmillan, 1960, 113-24.

Mohar, Tjaša and Michelle Gadpaille. "Alice Munro and Leonard Cohen: Ambassadors of Canadian culture in Slovenia." In Don Sparling, ed. Canada Consumed: The Impact of Canadian Writing in Central Europe (1990-2017). Brno: Masaryk University, 2019, 223- 240.

Mozzocco, J. Caleb. "War Bears”: a Review. The Comics Journal. 8 Nov 2019, http:// www.tcj.com/reviews/war-bears/.

Onič, Tomaž, Tjaša Mohar and Michelle Gadpaille. "The impact of Canadian literature in Slovenia since 1990." In Don Sparling, ed. Canada Consumed: The Impact of Canadian Writing in Central Europe (1990-2017). Masaryk University, 2019, 131-144.

Oppenheim, Maya. "Margaret Atwood: Feminism is not about believing women are always right." The Independent, 18 July 2017, https://www.independent. co.uk/arts-entertainment/books/news/margaret-atwood-handmaids-tale-author-feminism-women-not-always-right-a7847316.html. 
Staines, David. "Margaret Atwood in her Canadian Context." In The Cambridge Companion Margaret Atwood, edited by Coral Ann Howells. Cambridge University Press, 2006, 12-27.

Sullivan, Rosemary. The Red Shoes: Margaret Atwood Starting Out. HarperCollins, 1998.

Toye, William. The Concise Oxford Companion to Canadian Literature. Oxford University Press, 2001.

Tomaž Onič

University of Maribor tomaz.onic@um.si

Michelle Gadpaille University of Maribor michelle.gadpaille@um.si

Jason Blake

University of Ljubljana JasonFrederick.Blake@ff.uni-lj.si

Tjaša Mohar

University of Maribor tjasa.mohar@um.si

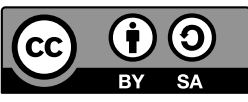

\section{Margaret Atwood - pisateljica svetovnega slovesa, a mnogim slovenskim bralcem še neznana}

Margaret Atwood je edina kanadska avtorica, katere 80-letnico so jeseni 2019 obeležile akademske skupnosti po vsem svetu. To ne preseneča, saj je najpopularnejša kanadska pisateljica, cenjena tudi zunaj literarnih krogov. Slovenski kanadianisti smo njen visoki jubilej obeležili z literarnim dogodkom v Univerzitetni knjižnici Maribor, na katerem smo predstavili avtoričin opus ter izbor njenih pesmi in odlomkov iz njenih del, pri čemer smo nekatera besedila prevedli posebej za to prireditev. Od njenega bogatega in raznolikega opusa je bilo doslej poslovenjenih le osem romanov, nekaj krajših proznih besedil in nekaj deset pesmi. Pričujoči članek želi bralstvu približati predvsem tiste vidike avtoričinega 
opusa, ki so v slovenskem prostoru manj znani oz. še neznani. Tudi pri nas ni skrivnost, da Margaret Atwood - predvsem zaradi Dekline zgodbe oz. televizijske nadaljevanke, posnete po literarni predlogi - pogosto označujejo za feministično pisateljico, manj znano pa je, da piše tudi poezijo, kratko prozo, knjige za otroke ter esejska in kritiška besedila, da je izjemno okoljsko osveščena ter da je posnela niz predavanj na temo zadolževanja in senčne plati bogastva. Le malokateri literat se tako uspešno kot ona preskuša v vseh žanrih in je hkrati ljubljenec kritikov in občinstva. Slednje zanjo velja tudi v slovenskem prostoru, zato lahko brez zadržkov upamo, da bodo slovenski založniki domačemu bralstvu približali še več njenih del. Margaret Atwood kljub častitljivi starosti še ne namerava zaključiti svoje kariere: tik pred okroglo obletnico je na turneji po Evropi predstavljala svoj zadnji roman Testamenti, s čimer bi nadaljevala v letu 2020, če ji tega ne bi preprečila pandemija.

Ključne besede: Margaret Atwood, kanadska književnost, književni prevod, žanri 